Јосип Силић

\title{
СИНТАГМАТСКИ И ПАРАДИГМАТСКИ КАРАКТЕР ГРАМАТИЧКИХ МОРФЕМА
}

(Њихова улога при успостављању синтактичких односа)

Јединица $а$ у облику кућа (при суодносу кућа ↔ куће $\leftrightarrow к у \hbar и \leftrightarrow н)$, у коју су укључена три грамема: „номинатив”, „једнина”, „женски род”, што значи да је хомонимична (синкретична), потврђује тезу о асиметрији суодноса сигнанса (означитеља) и сигнатума (означеног). Но та се асиметрија (сигнанса $a$ и сигнатума̄ „номинатив”, „једнина”, „женски род”) може докинути ако се суоднос (сигнанса $a$ и сигнатума̄ „номинатив”, „једнина”, „женски род”) прикаже овако: $1 . a \leftrightarrow$ „номинатив”, 2. a $\leftrightarrow$ „једнина", 3. $a \leftrightarrow$ „женски род”. Такво је приказивање суодноса сигнанса $a$ и сигнатума̄ „номинатив”, „једнина”, „женски род” методолошки оправдано из неколико разлога. Један је од њих тај што се, на тај начин, категорије (овдје категорија падежа, категорија броја и категорија рода) проматрају самостално, унутар себе, тј. унутар суодноса властитог израза и садржаја, па онда и унутар себи инхерентне опреке, а то омогућава да се успјешније објасни карактер синтактичких односа који су њима увјетовани. Једне увјетују једне, а друге друге синтактичке односе. Тако категорија падежа увјетује однос непосредних саставница $V$ и $N(V+N)$, у којем није релевантна присутност категорије броја и категорије рода. Категорија броја увјетује однос непосредних саставница $N$ и $V(N+V)$, у којем није релевантна присутност категорије броја и категорије рода. Категорија броја увјетује однос непосредних саставница $\mathrm{N}$ и $\mathrm{V}(\mathrm{N}+\mathrm{V})$, у којем није релевантна присутност категорија падежа и категорија рода. Категорија пак рода увјетује однос непосредних саставница $A$ и $N(A+N)$, y којем није релевантна присутност категорије падежа и категорије броја. То значи да синтактички однос $V+N$ укључује (као релевантну) категорију падежа, а искључује (као релевантну) категорију падежа и категорију рода, а да синтактички однос $A+N$ укључује (као релевантну) категорију рода, а искључује (као релевантну) категорију падежа и кате- 
горију броја. Другим ријечима, за однос $V+N$ свеједно је у којем ће се непосредна саставница $N$ налазити броју и роду: видим кућу (град, село), видим куће (градове, села), приближавам се кућама (градовима, селима) итд., за однос $N+V$ у којем ће се непосредна саставница $N$ налазити падежу и роду: кућа (град, село) има, куће (градови, села) имају, кући (граду, селу) не одговара, кућама (градовима, селима) не одговара итд., а за однос $A+N$ у којем ће се непосредна саставница $N$ налазити падежу и броју: велика кућа (велики град, велико село), велике куће (велики градови, велика села), великој кући (великом граду, великом селу), великим кућама (великим градовима, великим селима) итд. Како пак однос $V+N$ има парадигматски, а односи $N+V$ и $A+N$ синтагматски карактер, категорија падежа има парадигматски, а категорија броја и категорија рода синтагматски карактер.

Једино ће се тако, по нашем мишљењу, моћи објаснити односи успостављени облицима типа дјеца. Односи дјеца $\leftrightarrow$ дјеце $\leftrightarrow$ дјеци $\leftrightarrow$ н, наша дјеи а $\leftrightarrow$ наше дјеце $\leftrightarrow$ нашој дјеии $\leftrightarrow$ н, дјеия слушају и дјеиа су послушна говоре о томе да се синкретично а у кућа и синкретично $а$ у дјеца и подударају и не подударају. Подударају се парадигматски, тј. у категорији падежа (куће и дјеце, наше куће и наше дјеще), али не и синтагматски, тј. у категорији броја и у категорији рода (кућа има, али дјеца имају; кућа је велика, али дјеца су велика). (Док а у кућа значи једнину, дотле а у дјеца значи множину; док $а$ у кућа значи женски род, дотле $a$ у дјеца значи средњи род.) Тако се понашају још облици типа двојица и облици типа zосnода.

О методолошкој оправданости „еманципираног” проматрања категорија о којима је ријеч говори и то што има облика у којима имају одвојене (несинкретизиране) формалне ознаке. Тако се у облицима типа теле категорија падежа остварује формалном ознаком $\varnothing$, а категорија рода формалном ознаком $e$ // em (номинатив: $т е л-e-\varnothing$, генитив: $m е л$ $-e m-a)$.

У вези с тиме чини нам се да би категорију броја у ријечима таква типа, ако се сматра да је имају, требало проматрати унутар суодноса $(e) e m$ $\leftrightarrow$ ад, гдје би, у том случају, ад требало тумачити као граматички морфем.

Такве су јединице, јединице типа ад (и, опћенито, јединице које су носиоци граматичких значења броја и рода), подложне лексикализирању. Понекад се или фузионирају с јединицама основе, те тако постају њезиним саставним дијелом, или попримају карактер лексичких (деривацијских) морфема (тј. морфема с лексичким или лексикализираним значењем). Тако, на примјер, споменута јединица у ријечима типа момчад више нема оно своје (граматичко) значење које има у ријечима типа 
телад. Стопивши се с основом, постала је дијелом структуре израза која претказује другачији избор граматичких морфема, а с њима и другачији избор грамема.

Јединица се пак ес у облицима тјелеса и чудеса може тумачити двојако: или као јединица која претказује множину (као јединица ов у облицима типа градови), па у том случају има грамат. улогу. (У прилог тумачењу јединице ес као граматичке јединице може говорити облик небеса.) Једно је ипак јасно: чим се одвојила од једног дијела основе (дијела основе за облике једнине), добила је могућност да дијелове основе поларизира лексички, па чак и да их потпуно, граматички, еманципира. (Примјер ушеса показује да може попримити и својеврсну улогу деривацијског морфема - с аугментативно-пејоративним значењем.)

Двојакост улоге јединице ес (граматичке и лексичке) објашњава се тиме што постоје деривати који претпостављају једну (алтернирану) основу и деривати који претпостављају двије (неалтернативне) основе. Тако деривати тјелесан и небески претпостављају једну (алтернирану) основу: $m($ uje//je) $)(\varnothing / /$ ec $)(o)+$ ан и неб( $\varnothing / / e c)(o)+(c) \kappa u$, а деривати чудан и чуд( $\varnothing / / е c)(o)+a н$. (Због заједничког основског дијела чуд- и деривати се чудан и чудесан могу мотивирати „заједничком” основом: чуд( $\varnothing / /$ ec)-. Но у том случају јединицу ес треба сматрати лексикализираном. - То је и разлог што се у примјерима тип неб $(\varnothing / e c)(o)+(c) \kappa u$ и $m($ uje//je)л $(\varnothing / /$ ec) $(o)+a н$ јединица $е c$ не може, а у примјерима типа чуд( $\varnothing / / e c)(o)+a н$ може одвојити од основе. Другим ријечима, у првом случају, кад је ријеч о примјерима типа небески и тјелесан ${ }^{1}$, јединица се ес не може, а у другом случају, кад је ријеч о примјерима типа чудесан, може придружити деривацијском морфему: небес-(c)ки и тјелес-ан, али чуд-есан.)

Јединице типа ес могу бити „помичне” (када имају граматичку улогу) и „непомичне” (када имају лексичку улогу). „Помичне” су у примјерима типа небо: небеса (небески), „помично-непомичне” у примјерима типа чудо : чуда : чудеса (чудан, чудесан), а „непомичне” у примјерима типа пламен. (И јединица је ен у пламен била некада „помична”: плам-y-// плам-ен-. Данас је она лексикализирана - саставни је дио основе пламен-. Да су и оне биле некад „помичне”, показују деривати типа пламичак - према пламеник. Због тога би њихову, творбену, мотивацију требало приказивати овако: плам $(\varnothing / / е н)(\varnothing)+$ чак.)

1 Такве се варијантне основе у процесу развоја језика често еманципирају и преузимају различите функције: једна се почиње употербљавати у једној, а друга у другој функцији - једна обично у опћекњижевнојезичној, а друга у терминологијској. Тако се недавно, у имунологијској терминологији, појавила и основа тијел- (усп. протутијелни или антитијелни имунитет). 
Анализирани примјери могу нам показати: 1. да се основе с основским проширцима могу нивелирати двојако: укључивањем основских проширака (усп. пламен : пламена) и искључивањем основских проширака (усп. небо : неба); 2. да такво нивелирање може захватити и цијелу парадигму, тј. и једнину и множину (усп. пламен- $a$ ), и дио парадигме, тј. или само једнину (усп. неб-а) или само множину (усп. небес-а). Нивелирање основе без основских проширака може истиснути основу с основским проширцима (усп. неб- $a$ - истиснута основа небес- $a$ ), а нивелирана основа с основским проширцима - основу без основских проширака (усп. небес- $a$ - истиснута основа неб- $a$ ). Но могуће је и да основа с основским проширцима дјелује успоредо с основом без основских проширака (усп. чудес- $a$ и чуд- $a$, језериет- $a$ и језери- $a)^{2}$.

Бисмо ли, с обзиром на оно што је досад речено, могли закључити да род и број осим о граматичкој овисе и о лексичкој семантици? Није ли управо то, што су род и број подложни лексичкој семантици, разлог зашто се односи рода и броја међу синтактичким јединицама, кад за то не постоје граматички увјети, остварују лексичким средствима? У вези с тиме могли бисмо рећи: тамо гдје постоји граматичка ознака за мушки род, тамо је мушки род (усп. овај град); тамо гдје постоји граматичка ознака за женски род, тамо је женски род (усп. ова кућа); тамо гдје постоји граматичка ознака за средњи род, тамо је средњи род (усп. ово село); тамо гдје не постоји граматичка ознака за средњи род, гдје нема рода, тамо је средњи род (усп. ово доба, кад $а$ није ознака за род, и ова доба, кад је а ознака за род). Слично се може рећи и за број (тамо гдје постоји граматичка ознака за множину, тамо је множина: ови градови; тамо гдје не постоји ни граматичка ознака за једнину ни граматичка ознака за множину, гдје уопће нема граматичке ознаке за број, тамо је једнина: ово и). Управо се зато однос између синтагме много људи и синтагме стићи на прославу остварује и средњим родом и једнином: Много тьуд стигло је на прославу.

Једнином се успоставља однос и кад се јединице о којима је ријеч збрајају (усп. Двадесет одраслих тьди и неколико дјеце стигло је јутарним влаком). Кад се пак збрајају јединице с граматичким ознакама (ријеч је о граматичким ознакама једнине), о томе какав ће се однос успоставити зависи од тога јесу ли јединице које се збрајају испред или иза

2 Кад је ријеч о стилистички увјетованој употреби основа о којима је ријеч, треба имати на уму то да употреба може бити било неутрална, кад ниједна основа није стилистички маркирана, било ненеутрална, кад је једна основа стилистички маркирана. 
вербалне синтагме (у антепозицији или у постпозицији). Ако су јединице које се збрајају испред вербалне синтагме (у антепозицији), однос се остварује множином (усп. Иван и Невен долазе јутарним влаком). Ако су пак јединице које се збрајају иза вербалне синтагме (у постпозицији), однос се остварује било једнином (усп. Јутарним влаком долази Иван, Невен и Марин) било множином (усп. Јутарғим влаком долазе Иван, Невен и Марин).

Слично се догађа и кад се однос успоставља родом. Но притом треба имати на уму то да јединице које се збрајају могу бити, с гледишта рода, хомогене и хетерогене: могу бити само с ознаком мушког рода, само с ознаком средњег рода, само с ознаком женског рода те с ознаком мушког и средњег, мушког и женског, средњег и женског, мушког, средњег и женског рода. Кад су јединице које се збрајају испред вербалне синтагме (у антепозицији), могуће је ово: 1. ако су посриједи јединице само с ознаком мушког рода, само с ознаком средњег рода или с ознаком мијешаног рода, однос се успоставља мушким родом (усп. Човјек и пас су се одмарали, Псето и маче су трчали за дјецом, Отаи и мајка су кренули на пут, Дијете и мајка су спавали у колима итд.); 2. ако су посриједи јединице само с ознаком женског рода, однос се успоставља женским родом (усп. Мајка и кћи кренуле су јутарғим влаком). Кад су пак јединице о којима је ријеч иза вербалне синтагме (у постпозицији), могуће је ово: 1. ако су посриједи јединице само с ознаком мушког рода, само с ознаком средњег рода или с ознаком мијешаног рода, однос се успоставља било мушким родом (усп. На пут су кренули отаи, и син, За дјец,о су трчали псето и маче, С балкона су нас проматрали мати и син, $C$ терасе су се могли видјети гора и село подно юе итд.); 2. ако су посриједи јединице само с ознаком женског рода, однос се успоставља женским родом (усп. Пратиле су их мати и кћи - Пратила их је мати и кћu). Разлог зашто се глагол у прогресивном слиједу вербалне синтагме понаша другачије него у њезину регресивном слиједу јест у томе што у прогресивном слиједу вербалне синтагме има адитивно, а у њезину регресивном слиједу кумулативно значење. (Кумулативно значење глагола онемогућава да се оствари у једнини).

Иако норма прихваћа статус конструкција типа Много ғьуди стигло је на прославу какав је описан, све се чешће среће однос њихове номиналне и вербалне синтагме остварен множином (и одговарајућим родом, који овиси о карактеру одређенице) (усп. Много људи стигли су на прославу.) То је зато што се с мотивације односа одредбеницом (много) прелази на мотивацију односа одређеницом (људи). Исто се то догађа и конструкцијама с квантитативним одредбеницама које имају одго- 
варајуће граматичке ознаке (усп. Већина људи стигла је на прославу $\rightarrow$ Већина људи стигли су на прославу). (Упозоравамо да одређеница има граматичку ознаку која такав однос, граматички, не омогућава.)

Из свега што је речено могли бисмо закључити: 1. да категорија падежа има граматички, а категорија рода и категорија броја граматичко-лексички карактер; 2. да категорија падежа чини парадигматску, а категорија рода и категорија броја синтагматску ос деклинације; 3. да морфеми падежа удружују ријечи у парадигматске односе (што значи да бисмо их могли назвати парадигматским релацијским морфемима), а морфеми рода и морфеми броја - у синтагматске односе (што значи да бисмо их могли називати синтагматским релацијским морфемима) ${ }^{3}$.

${ }^{3}$ Ми смо синтагматске граматичке морфеме своједобно дефинирали као граматичке морфеме несинтактичког (нерелацијског) типа. Изложена интерпретација, међутим, показује да и они имају синтактички (релацијски) карактер, само другачији од синтактичког (релацијског) карактера парадигматских граматичких морфема. Усп.: Rosandić-Silić, Osnove morfologije i morfostilistike hrvatskoga književnog jezika (priručnik za nastavnike). Zagreb, Školska knjiga, 1979, 74-77. 